\title{
PENGARUH METODE PEMBELAJARAN PENEMUAN TERBIMBING TERHADAP HASIL BELAJAR DAN AKTIVITAS SISWA PADA MATERI POKOK SUHU DAN KALOR DI SMA NEGERI 1 LIMAPULUH
}

\author{
Latifa Sahara dan Ridwan Abdullah Sani \\ Jurusan Fisika FMIPA Universitas Negeri Medan \\ Jalan Willem Iskandar Pasar V Medan, Sumatera Utara \\ latifasahara93@gmail.com
}

\begin{abstract}
ABSTRAK
Penelitian ini bertujuan untuk mengetahui pengaruh metode pembelajaran penemuan terbimbing terhadap hasil belajar dan aktivitas siswa pada materi pokok Suhu dan Kalor di SMA Negeri Lima1 Puluh. Jenis penelitian adalah quasi eksperiment dengan desain two group pre-test dan post-test. Populasi penelitian adalah semua siswa kelas X semester I SMA Negeri 1 Limapuluh T.P. 2014 / 2015. Sampeldiambil dengan teknik cluster random sampling, yang terdiri dari dua kelas, kelas eksperimen diterapkan metode pembelajaran penemuan terbimbing dan kelas kontrol diterapkan pembelajaran konvensional yaitu ceramah, memberi contoh soal dan soal latihan,siswa di kelas eksperimen berjumlah 30 orang dan di kelas kontrol sebanyak 32 orang. Data diperoleh dengan menggunakan Instrumen berupa tes pilihan berganda sebanyak 20 soal dengan 5 option (a,b,c, d, dan e). Berdasarkan hasil penelitian, setelah diberi perlakuan diperoleh rata-rata hasil belajar siswa di kelas eksperimen 78.83 sedangkan di kelas kontrol 74,69. Berdasarkan hasil analisis korelasi didapatkan signifikansi sebesar 0,000 pada taraf 0,01 yang artinya $\mathrm{H}_{\mathrm{a}}$ diterima, disimpulkan bahwa ada hubungan antara aktivitas belajar terhadap hasil belajar siswa yang diajarkan dengan metode pembelajaran penemuan terbimbing dan memiliki hubungan yang positif, yaitu jika aktivitas belajar meningkat maka hasil belajar juga akan meningkat dan berdasarkan uji hipotesis menggunakan uji beda (uji t) Ha diterima, diperoleh kesimpulan bahwa ada pengaruh yang berarti dari metode pembelajaran penemuan terbimbingsecara signifikan terhadap hasil belajar siswa pada materi pokok suhu dan kalor kelas X SMANegeri 1 Limapuluh T.P 2014/2015.
\end{abstract}

Kata Kunci: penemuan terbimbing, aktivitas siswa, hasil belajar, suhu dan kalor

\begin{abstract}
This study aimed to determinde the effect of Guided discovery learning method on learning outcomes and student activity at Temperature and Heat topic in SMA Negeri 1 Limapuluh. Research type was quasi-experimental with two group pre-test and post-test design. The population was all first semester students in class X SMA Negeri 1 Limapuluh Academic Year 2014/2015. Sample were taken by cluster random sampling technique consist of two classes, class experiment trieted with guided discovery learning method while class control with convensional learning,by examples of questions and exercises, the number of students in class experiment were 30 and in the control class were 32. Data obtained using instruments in the form of a multiple choice test as much as 20 questions with 5 options ( $a, b, c, d$, and e). Based on the results research, gained an average of student learning outcomes in class experiments 78.83
\end{abstract}


and class control 74.69. Based on the results of correlation analysis obtained a significance of 0.000 at the level of 0.01, that means Ha accepted, it was concluded there was a relationship between the activities and learning outcomes of students who are taught by guided discovery learning methods and have a positive relationship, if the learning activity increased, learning outcomes would beincreasedas well and based on hypothesis test using different test ( $t$ test) Ha accepted, the conclusion is there are significant effect of guided discovery learning method on the learning outcomes of students at temperature and heat topic class X SMA Negeri 1 Limapuluh Academic Year 2014/2015.

Keywords : guidance discovery, students activity, students outcomes, temperature and heat

\section{PENDAHULUAN}

Perkembangan ilmu pengetahuan dan teknologi yang teramat pesat saat ini, telah mempermudah kehidupan manusia. Mengingat fisika merupakan salah satu mata pelajaran yang penting karena ilmu fisika digunakan dalam kehidupan seharihari dan kemajuan teknologi maka sudah sewajarnya mata pelajaran fisika dikembangkan dan diperhatikan oleh semua pelaku pendidikan. Namun, fakta di lapangan menunjukkan bahwa hasil belajar peserta didik dalam pelajaran fisika masih sangat rendah.

Berdasarkan studi pendahuluan, diketahui bahwa hasil belajar peserta didik dalam pelajaran fisika di SMA $\mathrm{N} 1$ Limapuluh juga masih rendah. Hal tersebut dapat dilihat dari rendahnya nilai ujian yang diperoleh peserta didik. Berdasarkan data yang didapatkan nilai rata-rata ujian siswa adalah 45,7. Sedangkan KKM untuk pelajaran fisika di sekolah tersebut adalah 75. Nilai rata-rata siswa masih jauh di bawah KKM.

Salah satu faktor yang mempengaruhi rendahnya hasil belajar peserta didik dalam pelajaran fisika di SMA N 1 Limapuluh adalah karena metode dan teknik pembelajaran fisika yang dilakukan oleh guru tidak membuat peserta didik aktif belajar. Hal tersebut dibuktikan dari hasil observasi di SMA Negeri 1 Limapuluh dengan memberikan angket kepada 36 orang siswa pada tanggal 22 November 2014, sebesar $38,8 \%$ peserta didik menyatakan bahwa pelajaran fisika itu sulit dan kurang menarik, hal ini disebabkan karena guru mereka lebih dominan melakukan pembelajaran satu arah seperti menjelaskan materi, menulis rumus, memberikan soal dan memberikan tugas rumah, sehingga peserta didik dalam pembelajaran fisika menjadi penerima informasi yang pasif. Pernyataan tersebut terlihat dari sekitar $88,8 \%$ peserta didik menyatakan bahwa cara guru mereka mengajar di kelas adalah dengan cara mencatat dan mengerjakan soal. Siswa lebih banyak belajar dengan menerima, mencatat dan menghafal pelajaran. Hal inilah yang menyebabkan hasil belajar fisika yang diperoleh peserta didik kurang maksimal.

Faktor lain yang ditemukan peneliti adalah aktivitas belajar peserta didik dalam belajar fisika masih sangat rendah, sehingga berpengaruh kepada hasil belajar yang rendah pula. Pernyataan tersebut didukung oleh hasil angket, hanya $38,8 \%$ peserta didik yang senang mengerjakan soal di depan kelas. Serta hanya $11,11 \%$ peserta didik yang pernah mengemukakan pendapat di depan kelas pada saat belajar Fisika. Dari data tersebut dapat disimpulkan bahwa aktivitas belajar peserta didik masih tergolong rendah dan mempengaruhi hasil belajar.

Gulo (2002: 8-9) menyatakan bahwa mengajar adalah usaha untuk menciptakan sistem lingkungan yang memungkinkan terjadinya proses belajar 
secara optimal. Metode pengajaran juga menjadi salah satu komponen dalam menciptakan sistem lingkungan tersebut. Ada berbagai metode pengajaran yang perlu dipertimbangkan dalam strategi belajarmengajar. Ini perlu, karena ketepatan metode akan mempengaruhi bentuk strategi belajar-mengajar.Dalam rangka mendorong dan mengembangkan aktivitas peserta didik, guru harus mampu mendisiplinkan peserta didik, terutama disiplin diri (selfdiscipline). Dalam hal ini, guru harus mampu memerankan diri sebagai pengemban ketertiban, yang patut digugu, ditiru dan diteladani, tetapi tidak bersikap otoriter (Mulyasa, 2013: 45-45).

Salah satu metode yang dapat dijadikan alternatif adalah metode pembelajaran penemuan terbimbing (guided discovery). Temuan terbimbing adalah suatu pendekatan mengajar dimana guru memberi siswa contoh-contoh topic spesifik dan memandu siswa untuk memahami topik tersebut (Eggen dan Kauchak, 2012: 177). Menurut Sund dalam Roestiyah (2008: 20), discovery adalah proses mental dimana siswa mampu mengasimilasikan suatu konsep atau prinsip yang dimaksudkan dengan proses mental antara lain adalah: mengamati, mencerna, mengerti, menggolong-golongkan, membuat dugaan, menjelaskan, mengukur, membuat kesimpulan dan sebagainya. Dalam teknik ini siswa dibiarkan menemukan sendiri atau mengalami proses mental itu sendiri, guru hanya membimbing dan memberikan instruksi sehingga situasi belajar-mengajar berpindah dari situasi teacher dominated learning menjadi situasi student dominated learning. Penggunaan teknik ini guru berusaha meningkatkan aktivitas siswa dalam belajar-mengajar.

Pada penelitian Candra, Eko dan Sunyoto (2012) yang meneliti penerapan model pembelajaran guided discovery pada materi pemantulan cahaya untuk meningkatkan berpikir kritis. Analisis uji gain ternormalisasi memberikan hasil peningkatan sebesar 0,40 untuk siswa yang diajar menggunakan guided discovery, dan
0,36 untuk siswa yang diajar menggunakan cooperative learning.Akinbobola (2010) juga melakukan penelitian dengan kesimpulan "Guided discovery approaches was the most effective in facilitating students' achievement in physics after being taught using a pictorial organizer" yang berarti bahwa "Penemuan terbimbing adalah yang paling efektif dalam memfasilitasi prestasi siswa dalam fisika setelah diajarkan menggunakan organizer bergambar". Materi yang sesuai dengan penerapan metode pembelajaran penemuan terbimbing adalah materi yang membahas tentang konsep dan generalisasi. Peneliti memilih materi suhu dan kalor karena banyak menuntut siswa untuk lebih aktif menemukan konsep dari suhu dan kalor.

Berdasarkan uraian di atas, perlu dilakukan penelitian dengan judul, "Pengaruh Metode Pembelajaran Penemuan Terbimbing Terhadap Hasil Belajar dan Aktivitas Siswa pada Materi Pokok Suhu dan Kalor di SMA Negeri 1 Limapuluh"

\section{METODE PENELITIAN}

Penelitian dilaksanakan di SMA Negeri 1 Limapuluh, Jln Besar Limapuluh Kota Asahan dimulai pada bulan Desember 2014 sampai bulan Mei 2015 tahun ajaran 2014/2015. Populasi penelitian adalah semua peserta didik kelas X Peminatan Ilmu Alam semester genapyang berjumlah 96 peserta didik dan terbagi dalam 3 kelas. Sampel diambil secara acak dengan menggunakan cluster random sampling. Sebagai kelas eksperimen adalah kelas $\mathrm{X}$ MIA 2 dengan jumlah peserta didik 30 orang dan diberi perlakuan metode pembelajaran penemuan terbimbing. Kelas kontrol adalah kelas $\mathrm{X}$ MIA 3 dengan jumlah 32 orang peserta didik dan diberi perlakuan menggunakan pembelajaran konvensional. Jenis penelitian ini adalah quasi eksperiment (eksperimen semu) yaitu penelitian yang dimaksudkan untuk mengetahui ada tidaknya akibat dari sesuatu yang dikenakan pada subjek yaitu siswa, dengan menggunakan group pretestposttest design. Prosedur penelitian terdiri 
dari 3 tahapan yaitu tahap persiapan, tahap pelaksanaan dan tahap akhir. Untuk mengetahui hasil belajar siswa maka digunakan tes pilihan berganda sebanyak 20 butir yang divalidkan oleh 3 orang validator. Uji analisis data menggunakan program SPSS 15 dengan tahapan uji normalitas, uji homogenitas dan uji hipotesis yaitu uji t dan korelasi.

\section{HASIL PENELITIAN PEMBAHASAN \\ Hasil}

Sebelum kedua kelas diterapkan perlakuan yang berbeda, maka pada kedua kelas terlebih dahulu diberikan pretes yang bertujuan untuk mengetahui kemampuan awal belajar siswa.

Rata-rata nilai pretes yang diperoleh siswa pada kelas eksperimen adalah 34.17 dan pada kelas kontrol 31.25, hal inimenunjukkan bahwa nilai pretes pada kedua kelas tidak jauh berbeda, artinya kedua kelas mempunyai kemampuan awal yang sama dan perolehan nilai kedua kelas merata. Setelah memperoleh data hasil pretes siswa dari kelas eksperimen dan kelas kontrol, maka dilakukan terlebih dahulu uji asumsi data berupa uji normalitas dan uji homogenitas data pretes untuk mengetahui kelayakannya sebelum diberikan perlakuan.

Berdasarkan hasil output uji normalitas dengan menggunakan uji Kolmogorov-Smirnov nilai signifikansi data nilai pretes untuk kelas eksperimen dan kelas kontrol lebih besar dari 0,05, maka diterima. Hal ini berarti sampel dari kelas eksperimen dan kelas kontrol berasal dari populasi yang berdistribusi normal. Pada hasil output uji homogenitas nilai signifikansi lebih besar dari 0,05 maka tidak terdapat perbedaan varians antara kelas eksperimen dan kelas kontrol.

Selanjutnya dilakukan uji kesamaan rata-rata dengan menggunakan uji t. Karena nilai signifikansi lebih besar dari 0,05, maka di terima. Ini menunjukkan bahwa hasil belajar fisika siswa dari kedua kelas tersebut tidak berbeda secara signifikan.

Dua kelas tersebut kemudian di berikan perlakuan berbeda, selanjutnya kedua kelas diberikan postes dengan soal yang sama seperti soal pretes untuk mengetahui ada tidaknya pengaruh model yang diterapkan.

Rata-rata nilai postes yang diperoleh siswa pada kelas eksperimen adalah 79.83 sedangkan pada kelas kontrol 74,69 , hal ini menunjukkan bahwa penerapan metode pembelajaran penemuan terbimbing baik untuk diterapkan.

Berdasarkan hasil uji normalitas dan uji homogenitas diperoleh bahwa data berdistribusi normal dan homogen, sehingga dapat dilanjutkan uji kesamaan rata-rata dengan menggunakan uji $t$ satu pihakuntuk melihat pengaruh dari perbedaan metode pembelajaran antar kelas kontrol dan eksperimen. Didapat $\mathfrak{t}_{\text {hitung }}$ adalah 2,171 sedangkan $t_{l-\alpha}$ diperoleh 2,000. Ternyata $t_{\text {hitung }}>t_{0,975(60)}$ maka $\mathrm{H}_{0}$ ditolak. Hal ini berarti bahwa hasil belajar fisika siswa yang menggunakan metode pembelajaran penemuan terbimbing lebih baik daripada hasil belajar fisika siswa yang menggunakan pembelajaran konvensional.

Selama proses pembelajaran berlangsung, peneliti juga melakukan observasi yang bertujuan untuk mengamati aktivitas belajar siswa selama pembelajaran dengan metode pembelajaran peneman terbimbing.Berdasarkan observasi, didapat rata-rata aktivitas siswa adalah 84 atau berada dalam kategori sangat baik.

Setelah didapatkan data hasil belajar dan aktivitas siswa, selanjutnya diukur keeratan hubungan antara aktivitas belajar terhadap hasil belajar siswa menggunakan metode pembelajaran penemuan terbimbing dengan uji korelasi person atau dikenal juga dengan korelasi product moment. Berdasarkan hasil uji korelasi dapat disimpulkan bahwa ada hubungan antara aktivitas belajar terhadap hasil belajar siswa yang diajarkan menggunakan metode pembelajaran penemuan terbimbing dan 
jika aktivitas belajar meningkat maka hasil belajar juga akan meningkat.

\section{Pembahasan}

Selama proses pembelajaran siswa diajak untuk berperan aktif dalam pembelajaran seperti memberikan hipotesis, merancang percobaan, mencari informasi, menganilis data, membuat kesimpulan serta memberikan banyak kesempatan untuk bertanya baik sesama siswa maupun dengan peneliti sehingga siswa di dalam pembelajaran bukan sebagai penerima informasi yang pasif tetapi berperan aktif sebagai siswa yang ingin belajar dan ingin tahu. Peneliti juga menarik perhatian siswa dengan cara mengaitkan materi yang sedang dipelajari dengan kehidupan seharihari sehingga siswa akan lebih tertarik membahas topik pelajaran yag sedang dipelajari. Selain itu siswa diberikan LKS sebagai panduan praktikum yang dilengkapi dengan pertanyaan setelah praktikum yang dapat membantu siswa dalam memahami materi.

Setelah pembelajaran selesai dilaksanakan, peneliti memberikan postes menggunakan instrumen yang sama seperti pretes. Nilai rata-rata postes kelas eksperimen 79,83 dan kelas kontrol sebesar 74,89 . Nilai ini menunjukkan hasil belajar siswa kelas ekperimen yang diberi perlakuan dengan metode pembelajaran penemuan terbimbing lebih tinggi dari pada kelas kontrol. Setelah postes dilaksanakan dilakukan pengujian hipotesis. Hasil uji hipotesis untuk postes menggunakan uji $t$ satu pihak pada taraf signifikan $=0,05$ diperoleh $t_{\text {hitung }}>t_{\text {tabel }}(2,171>2,000)$ yang berarti bahwa ada pengaruh metode pembelajaran penemuan terbimbing terhadap hasil belajar siswa.

Berdasarkan uji korelasi

menggunakan korelasi product moment utuk mengetahui hubungan antara aktivitas belajar dengan hasil belajar siswa mengguakan metode pembelajaran penemuan terbimbing dapat disimpulkan bahwa ada hubungan antara aktivitas belajar terhadap hasil belajar siswa yang diajarkan menggunakan metode pembelajaran penemuan terbimbing. Korelasi antara hasil belajar dengan aktivitas siswa didapat nilai koefisien sebesar 0.744, karena koefisien mendekati 1 maka dapat disimpulkan bahwa antara hasil belajar dengan aktivitas belajar siswa memiliki hubungan yang erat. Angka koefisien positif menunjukkan hubunga positif, yaitu jika aktivitas belajar meningkat maka hasil belajar juga akan meningkat.

Siswa lebih menyukai proses pembelajaran melalui praktikum daripada hanya sekedar ceramah dan mengerjakan soal saja, hal ini terlihat dari antusisme siswa ketika melakukan tahap demi tahap proses pembelajaran. Siswa juga terlatih untuk berfikir lebih kreatif lagi dan akan menambah pengalaman siswa dalam belajar serta mendukung siswa untuk lebih aktif mengikuti kegiatan belajar.Pelaksanaan metode pembelajaran penemuan terbimbing dapat berjalan baik, namun masih banyak yang harus dibenahi, baik dari segi perencanaan maupun dari segi pelaksanaannya. Metode ini memiliki banyak kelebihan diantaranya adalah dengan pengalaman sendiri siswa akan mengingat konsep yang telah didapatkannya dan akan lama bertahan diingatan mereka, kemudian memotivasi siswa untuk melanjutkan tugasnya sampai menemukan jawaban, siswa juga terlatih untuk berfikir lebih kreatif lagi dan akan menambah pengalaman siswa dalam belajar serta mendukung siswa untuk lebih aktif mengikuti kegiatan belajar. Dalam penelitian ini juga masih memiliki kelemahan diantaranyya adalah peneliti terkadang kurang bisa membuat kelas kondusif karna hampir semua siswa aktif dan tak jarang peneliti kewalahan karena ada beberapa siswa secara bersamaan yang meminta untuk dibimbing ataupun bertanya. Metode penemuan terbimbing juga memakan waktu yang lumayan lama sehingga terkadang peneliti tidak tepat waktu dalam mengakhiri proses pembelajaran. 


\section{KESIMPULAN DAN SARAN \\ Kesimpulan}

Berdasarkan hasil penelitian yang diperoleh dari hasil analisa data dan pengujian hipotesis maka dapat disimpulkan bahwa nilai rata-rata hasil belajar fisika siswa menggunakan metode pembelajaran penemuan terbimbing adalah 79,83 yang berarti lebih tinggi daripada nilai rata-rata kelas kontrol yang diberi perlakuan menggunakan pembelajaran konvensional yaitu 74.89. Berdasarkan hasil pengujian hipotesis diperoleh kesimpulan bahwa ada pengaruh metode pembelajaran penemuan terbimbing terhadap hasil belajar siswa dan pada pengujian korelasi di peroleh kesimpulan bahwa ada hubungan antara aktivitas belajar terhadap hasil belajar siswa yang diajarkan menggunakan metode pembelajaran penemuan terbimbing, korelasi juga menunjukkan hubungan positif yaitu jika aktivitas belajar meningkat maka hasil belajar juga akan meningkat.

\section{Saran}

Berdasarkan hasil dan kesimpulan dalam penelitian ini, maka peneliti mempunyai beberapa saran, yaitu kepada peneliti selanjutnya yang ingin meneliti tentang metode pembelajaran penemuan terbimbing dan ingin melihat aktivitas siswa sebaiknya menggunakan di amati oleh 3 atau lebih observer, 2 kelompok diamati oleh 1 observer agar lebih efektif dalam penilaian nya serta hendaknya memperhatikan ketersediaan alat dan keadaan alat yang akan digunakan dalam praktikum.Bagi peneliti selanjutnya maupun guru yang ingin menggunakan metode penemuan terbimbing, dalam pembagian anggota kelompok saat praktikum lebih baik jangan lebih dari lima siswa agar dapat mengontrol dan membantu siswa siswa dalam melakukan praktikum.

\section{DAFTAR PUSTAKA}

Akinbobola, A., (2010), "Constructivist Practices Through Guided Discovery Approach: The Effect Onstudents' Cognitive Achievement in Nigerian Senior Secondary School Physics". Eurasian Journal of Physics And Chemistry Education, Volume 2(1): 16.

Candra, E., Eko, S dan Sunyoto., (2012), "Penerapan Model Pembelajaran Guided Discovery pada Materi Pemantulan Cahaya untuk Meningkatkan Berpikir Kritis". Unnes Physics Education Journal, 1: 27.

Eggen, P and Kauchak, D., (2012), Strategi dan Model Pembelajaran Mengajarkan Konten dan Keterampilan Berpikir, PT. Indeks.

Gulo, W., (2002), Strategi Belajar Mengajar, GRASINDO (Gramedia Widasarana Indonesia), Jakarta.

Mulyasa, E., (2013), Pengembangan dan Implementasi Kurikulum2013, Rosda, Bandung.

Roestiyah., (2008), Strategi Belajar Mengaja, Rineka Cipta, Jakarta. 